\section{EREM 75/4}

Journal of Environmental Research, Engineering and Management Vol. 75 / No. 4 / 2019 pp. 30-39

DOI 10.5755/j01.erem.75.4.23073
Leachates from Landfill Sites in Thessaloniki, Greece: Effect of Aging

Received 2019/04

Accepted after revision 2019/12

\title{
Leachates from Landfill \\ Sites in Thessaloniki, Greece: \\ Effect of Aging
}

\section{Adamadios Koumalas}

School of Science and Technology, HOU, 18, Parodos Aristotelous str., 26222, Patras, Greece

\section{Athanasios Dounavis*}

University of Western Macedonia, UOWM, Koila, 50100, Kozani, Greece

School of Science and Technology, Hellenic Open University (HOU), GR-26222, Patras, Greece

\author{
Elli Maria Barampouti
}

School of Chemical Engineering, NTUA, 9, Heroon

Polytechniou str., 15780, Zografou, Greece

\section{Sofia Mai}

School of Chemical Engineering, NTUA, 9, Heroon

Polytechniou str., 15780, Zografou, Greece

*Corresponding author: adounavis@uowm.gr

Sanitary landfilling still is one of the most common management systems of solid urban wastes. The persistent environmental impact of landfills depends on leachate characteristics. The present study aimed at the characterisation of leachate from two landfill sites in the prefecture of Thessaloniki, Greece. Mavrorachi landfill stands in our study as a representative Greek active landfill site, which started operating in 2008. Tagarades landfill has stopped receiving waste since 2008 after 27 years of full operation. In this investigation, leachate samples were physico-chemically characterised so as to assess their pollution potential and their concentration in regard to the type and age of landfill. Elevated concentrations of inorganic and organic constituents were observed in the leachate composition. COD ranged from $2,490 \mathrm{mg} / \mathrm{L}$ to $19,700 \mathrm{mg} / \mathrm{L}$, while the respective range for BOD was 390-14,850 mg/L during a 35-year period. The $\mathrm{pH}$ values of the leachate samples presented more moderate fluctuations between 7.3 and 8.5 . In addition, the ammoniacal nitrogen content increased as landfill age increased, whereas heavy metal concentrations showed significant variations with a slight decreasing trend. The results presented in this paper proved that, as time passed, the values of most parameters decreased as biodegradable compounds are broken down while refractory compounds resist to biodegradation. Thus, the age has a pronounced influence on the composition of leachate. This study also focused on quantifying the level of contamination that leachates can potentially cause on a comparative basis by leachate pollution index (LPI). LPI values showed that pollution load was declining but is still not negligible after 33 years.

Keywords: Landfill, leachate characteristics, Mavrorachi, municipal solid wastes, Thessaloniki 


\section{Introduction}

Solid waste management is a universal issue affecting everyone. Governments along with individuals handle issues concerning waste management affecting productivity and health (Silpa et al., 2018). Globally, almost $37 \%$ of waste is currently dumped or disposed in landfill sites. From this percentage, only $8 \%$ is disposed in sanitary landfills with appropriate methane gas collection systems. The proper waste disposal and treatment, that sanitary landfills or other more sophisticated facilities offer, are an exclusive privilege of the countries of upper-middle and high income. The former presents the highest rate of landfilling $(54 \%)$, while in countries with higher income, this percentage drops to $39 \%$, since $35 \%$ of waste is diverted to recycle and compost systems and $22 \%$ to incineration (Silpa et al., 2018). In Greece, from the 67 million tonnes of solid waste produced, $86 \%$ is disposed in landfills according to the latest statistic data of Eurostat (2016). Currently, 79 landfill sites of municipal solid waste are in operation in Greece. Only a few sites have been closed and are under rehabilitation works. Despite the environmental goals set by EC, landfilling as a solid waste management scheme is still predominant due to a number of reasons including economic, environmental, political, technological and social (Torretta et al., 2017).

The landfilling of solid waste creates leachate from the liquids (including rainwater) that pass through waste deposits. Generally, leachate is considered as high strength wastewater with high conductivity, rich in ammonium and organic matter. It is the result of waste decomposition and includes microorganisms, their metabolic products and other materials that drain out of landfill sites. Thus, leachate can be described as a multi-component mixture of insoluble, soluble, inorganic, organic, non-ionic, ionic, and bacteriological substances in an aqueous solution. Since

\section{Materials and Methods}

Study areas. Thessaloniki is in Macedonia in Northern Greece. Located on the coast, it is the second largest city in Greece and boasts a busy commercial these components are water soluble, there is a high risk that they will leak in surface and groundwater. The leachate's chemical composition is strongly dependent on the type of a landfill (nature and age), as well as on the leaching rate, waste composition and precipitation (Afsar et al., 2015).

Through EU Landfill Directive (EEC/1999/31/EC), landfilling is improved all over Europe, by setting specific requirements for the design and operation of landfills, including the monitoring of leachate, surface water and groundwater. Monitoring is a perdurable process including all the phases of a landfill lifespan: development, operation and post-closure management. It may last over 50 years after the closure of a landfill site (LFTGN02, 2003).

Monitoring of composition and transformations proceeding in landfill leachates allows for the design of special leachate treatment plants and for forecasting of migration of pollutants contained in leachates to underground water. It is then possible to take actions to limit the negative impact of leachates on such water. Examples of the impact of landfill leachates on water and ground environment are given in numerous papers. Increased concentration of mineral (heavy metals) and organic compounds (aromatic and aliphatic hydrocarbons) was noted in underground water at the researched municipal waste landfill site (Szymański et al., 2018).

In that respect, this research work is performed at real sites in Greece. Specifically, the present study aims to analyse the physical and chemical composition of landfill leachates and to study the influence of landfill age on the characteristics of leachates that are collected from two sanitary landfill sites, an open and a closed one, at Central Macedonia that treat municipal solid waste from the Thessaloniki regional unit.

port. The responsibility for waste management in Thessaloniki city and the entire prefecture of Thessaloniki is the responsibility of FODSA, a public company 
managing waste for the Association of Local Authorities of the prefecture of Thessaloniki. It manages the treatment of waste from two million inhabitants living in the prefecture. Nowadays, all non-recyclable waste is delivered to Mavrorahi sanitary landfill site, which disposes of the waste produced across Thessaloniki Prefecture as well as additional non-recyclable waste from Halkidiki municipalities. The landfill site is operated by FODSA who designed and constructed the landfill to replace the former sanitary landfill site at Tagaredes, which closed in 2008 after it had reached its full capacity. These landfill sites that were used for the disposal of Thessaloniki municipal solid waste were set as the study object of this paper.

More specifically, the landfill of Tagarades is a public, fully-organised sanitary landfill which is located southeast of Thessaloniki. From 1982 until August 2008 (almost 27 years), Tagarades landfill received domestic waste (organic, paper, plastic, etc.), some industrial waste, hospital waste and some inert construction and demolition waste from the wider area of Thessaloniki, Greece.

Mavrorachi landfill has been in operation since 2008 and receives mixed municipal waste from the Thessaloniki Regional Unit. It is a non-hazardous waste landfill where the compacted solid waste is covered daily with soil. The landfill area has been separated in 4 well-defined cells. The two cells have been fully exploited from 2008 to 2014 and the $3^{\text {rd }}$ cell is currently used since 2015. The average daily production of leachate for the period 2016-2017 was approximately 200 $\mathrm{m}^{3} / \mathrm{d}$. Since 2007, a Material Recovery Facility (MRF) in Sindos has been operating, affecting the amount differentiated at MSW that is landfilled. Table 1 presents details of the landfill sites studied in this paper.

Table 1. Details of the landfill sites examined

\begin{tabular}{|c|c|c|c|c|c|c|c|}
\hline Name & Location & Coordinates & Area (m2) & Starting year & $\begin{array}{l}\text { End of landfill } \\
\text { life }\end{array}$ & $\begin{array}{l}\text { Initial amount of } \\
\text { MSW (tn/y) }\end{array}$ & $\begin{array}{l}\text { Final MSW } \\
\text { received (tn/y) }\end{array}$ \\
\hline Tagarades & $\begin{array}{l}\text { KALAMAKI } \\
\text { SITE, } \\
\text { THERMI }\end{array}$ & $\begin{array}{l}23.041876^{\circ} \\
40.463094^{\circ}\end{array}$ & $1,000,000$ & 1982 & 2008 & 215,000 & 620,000 \\
\hline Mavrorachi & $\begin{array}{l}\text { KLEFTIKA } \\
\text { ERYTHRA } \\
\text { KAMELI }\end{array}$ & $\begin{array}{l}22.989167^{\circ} \\
40.638056^{\circ}\end{array}$ & 757,440 & 2008 & - & 620,000 & 479,000 \\
\hline
\end{tabular}

Methodology. Data, concerning the leachate composition, used in this study were obtained from the performance results of Tagarades and Mavrorachi landfills for a six-year period (2012-2017). The long performance data records were statistically processed according to the principles of descriptive and inferential statistics presented in the Guidance on Monitoring of Landfill Leachate, Groundwater and Surface Water (LFTGN02, 2003). In order to reveal the effect of landfill age on the leachate characteristic and taking into consideration the operational status of the selected landfills, the following assumptions were adopted: leachate from the $3^{\text {rd }}$ cell of Mavrorachi corresponds to fresh leachate (landfill age: 1-2 years); leachate from the $1^{\text {st }}$ and $2^{\text {nd }}$ cell of Mavrorachi corresponds to landfill age 4-8 years, whereas leachate from Tagarades represents mature leachate (landfill age: 31-35).

Leachate analyses. The leachates samples were analysed for several physico-chemical parameters according to standard methods (APHA, 1998). The chemical composition of leachate is strongly dependent on many parameters, including initial composition of solid waste, the site's hydrology, the compaction degree, the climate and, last but not least, the landfill age. The leachate analysis included carbonaceous, nitrogenous and other parameters. More specifically, COD and BOD, TKN, ammonia, nitrite, nitrate, 
phosphorus, heavy metals, conductivity and $\mathrm{pH}$ were recorded and evaluated. Characteristics of leachate were analysed statistically over the whole period of analysis for young and mature landfills.

Leachate pollution index estimation. Leachate pollution index (LPI) is an index used to quantify the degree of possible contamination from urban landfills on a scale from 5 to 100 (Kumar and Alappat, 2005a, 2005b; Umar et al., 2010). By the use of this tool, the leachates pollution data can be presented in a uniform way. LPI estimation process includes the selection of pollutant variables and of their respective weights, the formulation of their sub-indices curves, and finally the aggregation of the selected variables to final calculation of LPI value (Kumar and Alappat, 2004).

\section{Results and Discussion}

Leachate is the liquid drainage resulting from a landfill site and is characterised by elevated concentrations of organic compounds (either susceptible to biological degradation or not), ammoniacal nitrogen, heavy metals and chlorinated organic and inorganic substances (Mor et al., 2006).

$\mathrm{pH}$. Leachates are generally characterised by $\mathrm{pH}$ values between 4.5 and 9 . The composition and type of the waste disposed in a landfill as well as the landfill age are the major factors that control the variations in leachate $\mathrm{pH}$ values. Generally, the $\mathrm{pH}$ of a young leachate is lower than that of a stabilised leachate (Bhalla et al., 2013). Data for pH values over a 35-years period are presented in Figure 1. The range of $\mathrm{pH}$ values of the leachate samples from the selected sites was from 7.3 to 8.5. The $\mathrm{pH}$ of the leachate increased by $13 \%$ during the first four years of operation of the landfill sites. Bhalla et al. (2013) also reported an increase over time in the $\mathrm{pH}$ value of leachates, which was attributed to the reduction of the partially ionised free (volatile fatty acids (VFA) content. The $\mathrm{pH}$ rise implied that steady state conditions were achieved between the processes that produce acids, such as lignin and cellulose degradation and processes that consume acids such as methane production during landfilling (Bhalla et al., 2013). Stabilised leachate presents fairly stable $\mathrm{pH}$ values with low fluctuations.
The LPI was estimated by the use of the following equation (equation (1)):

$$
L P I=\frac{\sum_{i=1}^{m} \mathrm{~W}_{\mathrm{p}} \mathrm{p}_{\mathrm{i}}}{\sum_{i=1}^{m} \mathrm{~W}_{\mathrm{i}}^{\mathrm{i}}}
$$

Where: LPI - the weighted additive leachate pollution index;

$\mathrm{w}_{\mathrm{i}}$ - the weight for the $i^{\text {th }}$ pollutant parameter;

$p_{i}$ - the sub-index score of the $i^{\text {th }}$ leachate pollutant parameter;

$\mathrm{n}$ - the number of leachate pollutant parameters used in the calculation of LPI and

$m$ - the number of leachate pollutant variables for which data is available and, thus, $\sum_{i=1}^{m} \mathrm{~W}_{i}<1$.

It ranged between 8.1 and 8.3. The older the landfill, the less variations in $\mathrm{pH}$ values, which is also confirmed in literature (Ngilangil et al., 2015).

Conductivity. Total dissolved solids (TDS) and conductivity (EC) are important parameters, influencing the pollution potential of leachates. The concentration of total dissolved solids reveals the degree of mineralisation. High TDS concentrations may alter the chemical and physical characteristics of the receiving water bodies (Umar et al., 2010). Conductivity values are strongly related to the total salts content in leachate, reflecting its total concentration of ionic substances. The ability of a solution to convey electrical current is quantified by conductivity. In the present investigation, the timeline of both TDS and EC for the 35-years period is illustrated in Figure 1. More specifically, the range of conductivity extended from 17.9 to $28.6 \mathrm{mS} /$ $\mathrm{cm}$ with a mean value of $23.8 \mathrm{mS} / \mathrm{cm}$ and the mean value of total dissolved solids was $13,805 \mathrm{mg} / \mathrm{L}$ for all young and mature leachate samples. Similar results were reported by Abd El-Salam et al. (2015), who collected leachates from landfills in Colombia and Morocco with conductivities of $22 \mathrm{mS} / \mathrm{cm}$ and $26 \mathrm{mS} /$ $\mathrm{cm}$, respectively (Abd El-Salam et al., 2015). However, higher conductivity values of $31.68 \mathrm{mS} / \mathrm{cm}$ were presented by Bahaaeldin et al. (2010), who studied the leachates from a landfill in Malaysia. 
Fig. 1. Variations with time in $\mathrm{pH}$, total dissolved solids and conductivity in leachates from the landfill sites of Central Macedonia.

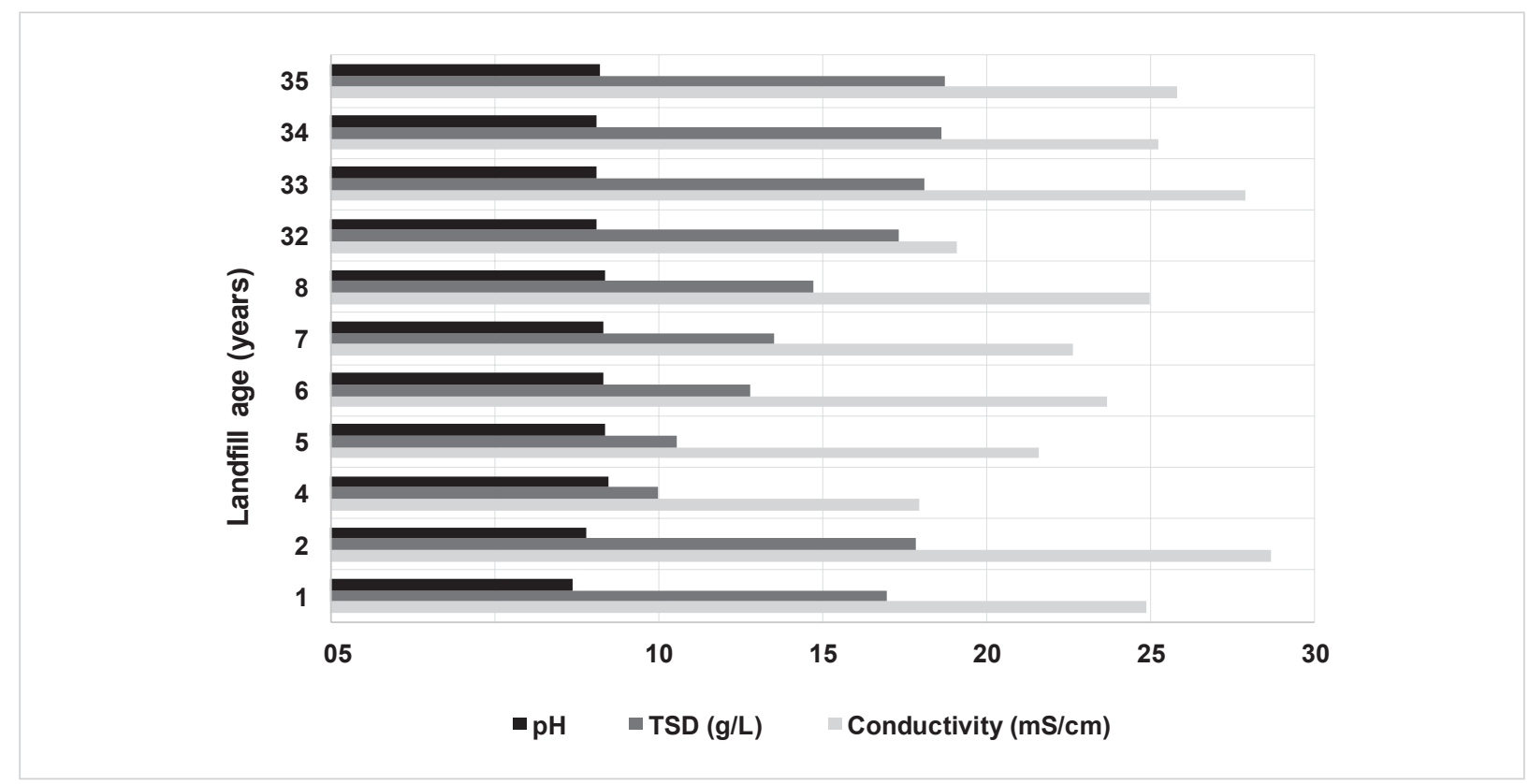

Carbonaceous parameters. As cited by Abd El-Salam et al. (2015), the chemical oxygen demand of leachates is in general within the range of 5,000-20,000 $\mathrm{mg} / \mathrm{L}$. In the first phase of acidogenic biodegradation, leachates are characterised by elevated $\mathrm{BOD}_{5}(4,000-13,000 \mathrm{mg} / \mathrm{L})$ and $\operatorname{COD}(30,000-60,000 \mathrm{mg} / \mathrm{L})$ values, while even higher BOD $(81,000 \mathrm{mg} / \mathrm{L})$ and COD $(70,900 \mathrm{mg} / \mathrm{L})$ values (Tatsi \& Zouboulis, 2002; Umar et al., 2010) have been reported.
As gleaned from the results presented in Figure 2, the COD values of the leachates studied ranged from 2,490 $\mathrm{mg} / \mathrm{L}$ to as high as $19,700 \mathrm{mg} / \mathrm{L}$.

Organics in leachates are characterised by different levels of biodegradability. Since the biodegradable organic content of leachate samples is quantified through BOD, these values usually decrease over time reflecting the landfill's maturity (Bhalla et al., 2013). In the current

Fig. 2. Trends in $C O D, B O D$ and $B O D 5 / C O D$ values in leachates from the landfill sites of Central Macedonia.

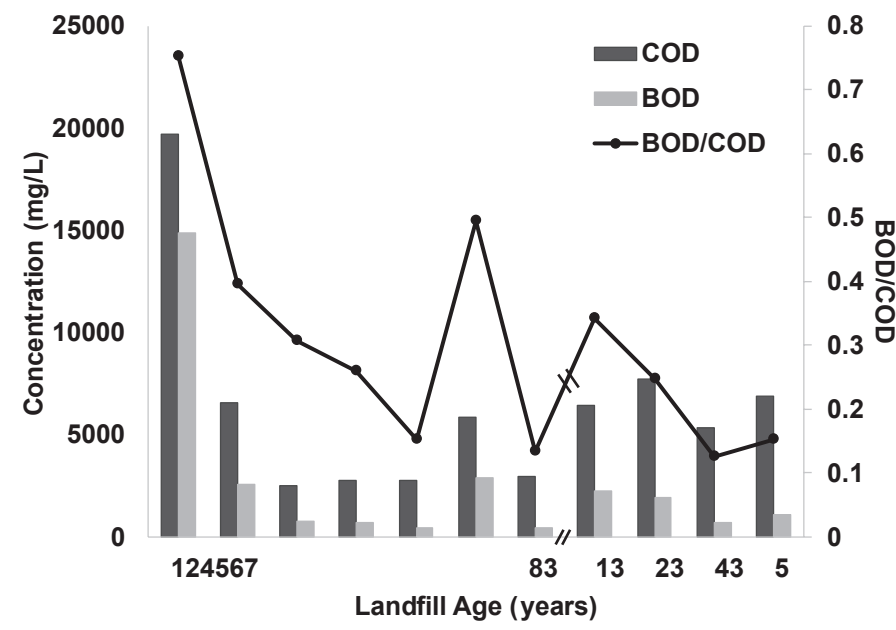


study, BOD of examined leachates at the landfilling sites ranged between $390-14,850 \mathrm{mg} / \mathrm{L}$. The whole timeline of BOD as presented in Figure 2 indicates that BOD varies with respect to the age of landfills. The $\mathrm{BOD}_{5} / \mathrm{COD}$ ratio is a measure of the biodegradation degree of a sample and is related to the maturity of a landfill site. High $\mathrm{BOD}_{5} / \mathrm{COD}$ ratios indicate elevated concentrations of biodegradable organic compounds, while low $\mathrm{BOD}_{5} / \mathrm{COD}$ ratios reflect a resistance to biological degradation due to the predominance of non-biodegradable compounds (Bhalla et al., 2013). The $\mathrm{BOD}_{5} / \mathrm{COD}$ ratio for all the samples collected is also presented in Figure 2. The $\mathrm{BOD}_{5} / \mathrm{COD}$ ratio is in accordance with the results reported in literature (Aziz et al., 2007; Bhalla et al., 2013; Zainol et al., 2012).

From year 1 to year 6 , there is a distinct decrease in the concentration of the carbonaceous material as well as in its biodegradability. In year 7, a peak is observed that may be attributed to the initiation of the $3^{\text {rd }}$ cell's operation, at which point fresh leachate was mixed with leachates from the $1^{\text {st }}$ and $2^{\text {nd }}$ cells, for a short period. The mature leachate from Tagarades landfill site presents higher values of COD in respect to the corresponding values from Mavrorachi, since this landfill site was receiving all kinds of waste (municipal, industrial, hospital and demolition waste) and thus the initial organic loading was much higher.

This trend in biodegradability of leachates was verified by Szymański et al. (2018), who studied the variations in the chemical and physical parameters of leachates coming from municipal waste landfills located in Middle Pomerania. The authors noted that the biochemical activity indicator, expressed by $\mathrm{BOD}_{5} / \mathrm{COD}$ ratio, varied between 0.81 and 0.72 . After 5 years of landfill operation, those values were maintained within the range of $0.23-0.25$, which absolutely indicates a certain stabilisation of biochemical processes in the leachates. This originates from the fact that landfill leachates contained, at that time, a considerably high amount of hardly biodegradable substances, which were subjected to further biodegradation in the subsequent years. It is quite possible that part of organic substance was absorbed by argillaceous minerals (illite occurs there) or humus compounds (Szymański et al., 2018).

Nitrogen. In the development of management and treatment schemes of landfill leachates, soluble nitrogen should be specially cared since it is considered as a crucial long-term pollutant (Ngilangil et al., 2015). The concentration of ammoniacal nitrogen tends to increase with the passage of time (increase of landfill age), which can be attributed to the hydrolysis and the fermentation of nitrogenous fractions of organic bio-degradable compounds. (Umar et al., 2010) The fluctuations in nitrogenous compound concentrations of leachates in terms of total Kjeldahl nitrogen (TKN), ammonium nitrogen $\left(\mathrm{NH}_{4}-\mathrm{N}\right)$, nitrate $\left(\mathrm{NO}_{3}-\mathrm{N}\right)$ and nitrite $\left(\mathrm{NO}_{2}-\mathrm{N}\right)$ of the studied landfill sites is provided in Figure 3. The total Kjeldahl nitrogen includes the organic nitrogen (Org-N) and the ammoniacal nitrogen

Fig. 3. Trends in nitrogen species values in leachates from the landfill sites of Central Macedonia.

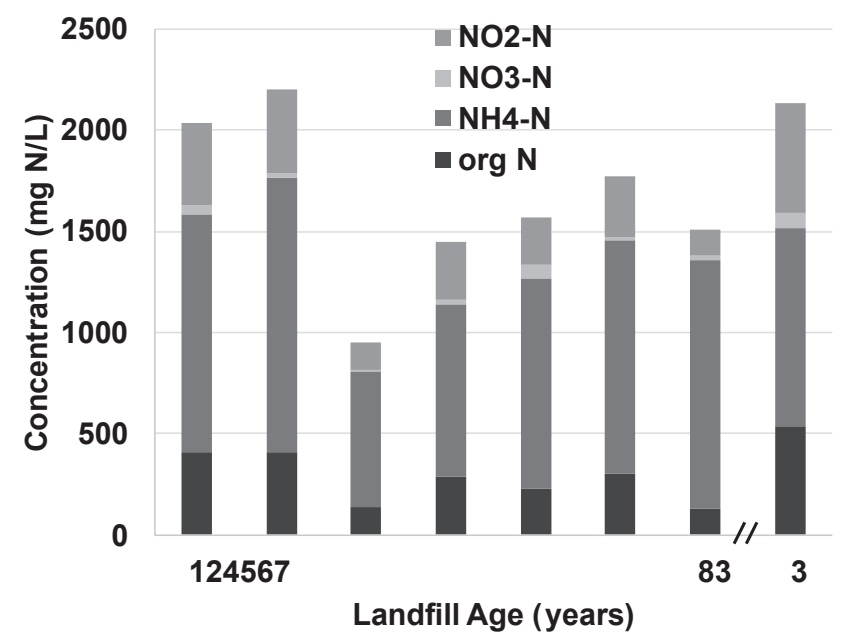


$\left(\mathrm{NH}_{4}-\mathrm{N}\right)$, as the main is representative of inorganic mass. Usually, the fractionation of nitrogen in the landfill leachates presents a small portion of organic nitrogen and a much higher fraction of $\mathrm{NH}_{4}-\mathrm{N}(60-90 \%$ of TKN) (Lema et al., 1988). Figure 3 illustrates that TKN in leachates varied from 800 to $1,800 \mathrm{mg} / \mathrm{L}$ for the sanitary landfills. The concentration of ammonia nitrogen follows the exact same pattern as TKN since it is the predominant species. The results of the present study are in accordance with those published in literature (Chu et al., 1994; Ehrig, 1983; Manning \& Robinson, 1989). Chu et al. (1994) stated that the ammonium nitrogen concentration of leachates moved in the range of 500 and $1,500 \mathrm{mg} / \mathrm{L}$ for landfill age 3-8 years and remained nearly constant at least for half a decade. The trend of the ammonia-nitrogen concentration is in full accordance with Robinson and Barr (1999), Manning and Robinson (1989) and Ehrig (1983).

During the first year of landfill operation, higher concentrations of nitrogen oxides were noted. This can be attributed to the fact that the redox potential presents positive values, which indicates oxidising conditions existing in landfill. This condition is maintained fairly stable during the next year although, after a short period (2 years of operation), conditions in this environment changed from aerobic to anaerobic, which was indicated by, among other, much higher concentration of ammonium ions than nitrogen oxides ions and negative redox potential. This was the case in the study of Szymański et al. (2018).

Heavy metals. The main sources of heavy metals in the urban solid waste are consumers' electronics, light bulbs, batteries, ceramics, paint chips and house dust, used motor oils, plastics, lead foils such as wine bottle closures, and some inks and glass. Heavy metal concentration in leachates is usually higher at initial phases of landfill operation due to elevated metal solubility that is related with low pH in the landfill caused by the organic acids production (Naveen et al., 2015). Their concentrations are presented in Table 2.

From Table 2, it is evident that leachates content of heavy metals presents significant variations. A general decreasing trend is observed. This is due to the decrease of $\mathrm{pH}$ over time, which in turn causes a reduction in the solubility of metals. Macroscopically, this fact leads to a rapid decrease in nearly all heavy metals concentration. Lead is an exception, since it is known that it produces heavy complexes with the present humic acids (Umar et al., 2010).

Table 2. Trace metals composition of leachates from the landfill sites of Central Macedonia

\begin{tabular}{l|c|c|c|c|c|c|c}
\hline \multicolumn{1}{c|}{$\mathrm{cc}$} & $\mathrm{Ni}(\mathrm{mg} / \mathrm{L})$ & $\mathrm{Cu}(\mathrm{mg} / \mathrm{L})$ & $\mathrm{Zn}(\mathrm{mg} / \mathrm{L})$ & Total Fe $(\mathrm{mg} / \mathrm{L})$ & $\mathrm{Cd}(\mathrm{mg} / \mathrm{L})$ & $\mathrm{Pb}(\mathrm{mg} / \mathrm{L})$ & $\mathrm{Total} \mathrm{Cr}(\mathrm{mg} / \mathrm{L})$ \\
\hline 1 & 4.42 & 9.22 & 6.05 & 57.79 & 0.24 & 4.49 & 4.34 \\
\hline 2 & 3.76 & 3.43 & 1.71 & 16.00 & 0.18 & 1.56 & 0.23 \\
\hline 7 & 1.57 & 2.15 & 2.91 & 71.10 & 0.40 & 6.73 & 0.58 \\
\hline 33 & 1.62 & 0.16 & 0.58 & 8.50 & 0.07 & 0.76 & 1.23 \\
\hline
\end{tabular}

Total phosphorus. Phosphates are another main component of leachates, deriving from many and different sources such as detergents, agricultural fertilisers, domestic wastes, industrial process wastes, etc. Total phosphorus concentrations for leachate at landfilling sites had a fair reduction over time from $22.11 \mathrm{mg} / \mathrm{L}$ (year 1) to $12.87 \mathrm{mg} / \mathrm{L}$ (year 33) with a mean concentration of $17 \pm 4 \mathrm{mg} / \mathrm{L}$ for all samples examined. The pattern was similar in the study of Szymański et al. (2018), but a more considerable reduction of phosphate ions concentration was noted. This could be attributed to the fact that phosphate ions generated hardly soluble chemical compounds.

Leachate pollution index. Aiming at the evaluation of leachates contamination potential over time in a uniform way, LPI was used as a very efficient method according to literature. In this study, the leachate pollution index was estimated by applying the Delphi technique (Kumar \& Alappat, 2004). The leachate pollutant parameters used for the estimation of LPI 
Table 3. LPI for the landfill leachate samples of Central Macedonia

\begin{tabular}{|l|c|c|c|c|c|c|c|c|}
\hline Landfill Age & 1 & 2 & 4 & 5 & 6 & 7 & 8 & 33 \\
\hline LPI & 49.66 & 31.94 & 34.45 & 38.82 & 40.18 & 33.86 & 42.24 & 27.48 \\
\hline
\end{tabular}

were $\mathrm{pH}, \mathrm{COD}, \mathrm{BOD}, \mathrm{TN}, \mathrm{NH}_{4}-\mathrm{N}, \mathrm{TDS}, \mathrm{Fe}, \mathrm{Cu}, \mathrm{Ni}, \mathrm{Zn}$, $\mathrm{Pb}$ and $\mathrm{Cr}(\mathrm{m}=12)$. The sub-index scores along with the weights of each leachate pollutant variable were selected accordingly from Kumar and Alappat (2005a) for all leachate samples of the landfill sites of Central Macedonia. By using equation 1, the LPI values presented in Table 3 were calculated.

The high LPI value (49.66) of landfill age, i.e., 1 year, implies that the physico-chemical and biological reactions are in progress, while the disposed waste has not yet stabilised. This high LPI value indicates that fresh leachates generated from a landfill during the first year of operation should be managed by application of proper treatment. Additionally, the landfill site should be monitored on a regular basis. For landfill ages 2-8 years, the respective LPI values move within the range of 31.94 to 42.24 . The latter indicates that LPI values are comparable, while the need for proper treatment remains. The low heavy metal concentration in the leachate for the respective time period is the principle reason for the these reduced LPI values. Similar LPI values have been reported for active landfill sites. For fresh leachates derived from landfills in China, Banqiao, Machen, and Jiuduhe, the LPI values were 36, 34, and 36, respectively (Yang et al., 2018). In the same context, for the Guanajuato landfill in Mexico, the LPI of fresh leachates was calculated equal to 34.8 (Guerrero-Rodríguez et al., 2014). The Pillar Point Landfill in Hong Kong, which is a landfill site (valley-fill) for domestic and commercial waste active since 1984, presented after 20 years of operation an LPI value of 36.48. Furthermore, Shuen Wan Landfill in Hong Kong which is a marine active landfill within a series of retaining seawalls after 24 years of operation has an LPI of 39.04 (Kumar \& Alappat, 2005b). Yang et al. (2018) stated that when the time period of landfill operation increased, the LPI values decreased. This is also the trend for the active landfill of Mavrorachi. Umar et al. (2010) pointed out that landfill sites of similar age presented similar LPI values. However, the absolute values of LPI reported in literature may present variations as a result of differences in waste composition reflecting diverse lifestyles and economic status of areas served. Seasonal variations in LPI values have also been reported. Kale et al. (2010) studied the influence of monsoons, while Yang et al. (2019) studied the impact of the precipitations on LPI value.

The fairly low value of LPI (27.48) of landfill age of 33 years (closed in 2008) implies that the leachates produced from Tagarades landfill have been to some extent stabilised and that aftercare monitoring may be modulated according to the national regulations. Although closed, it still has a contamination potential; therefore, it can threaten human health and water resources and, thus, suitable remediation plans and monitoring schemes should be applied. Each pollutant parameter should comply with the national emission limit values prior to any leachate disposal to the water bodies. Lower but accountable LPI values (15.97) were reported by Kumar and Alappat (2005b) for Nagu Chi Wan landfill (Hong Kong) after 12 years from its closure.

As far as the contribution of pollutant parameters on $\mathrm{LPI}$ is concerned in the present study, COD and ammoniacal nitrogen had the most pronounced contribution to the LPI, followed by total nitrogen and BOD.

\section{Conclusions}

Leachates are generated through the penetration of rain in the stacked waste of a landfill and the consequential leaching of minerals and soluble organic compounds. As presented in this study, the concentrations of most physico-chemical parameters that characterise leachate samples present significant variations during the lifespan of a landfill site. In the initial stages of landfill operation, the concentration of easily biological degradable substances in the leachate samples is high. During this stage, the metal concentrations are also elevated since metal ions present high solubility given the prevailing 
acidic conditions (low pH). As landfill sites age, their $\mathrm{pH}$ increases and their biodegradability decreases. This phenomenon results from the fact that leachates from landfill sites of young age present high concentrations in organic compounds that are susceptible to biodegradation. By the removal of biodegradable compounds, there is a continuous accumulation of non-biodegradable, refractory substances. For years 3 to 8 of the landfills' operation, the concentration of ammonia nitrogen in the leachates was in the range of 500 and $1,500 \mathrm{mg} / \mathrm{L}$ and

\section{References}

Abd El-Salam M.M. and Abu-Zuid G.I. (2015) Impact of landfill leachate on the groundwater quality: A case study in Egypt. Journal of Advanced Research 6(4): 579-586. https://doi. org/10.1016/j.jare.2014.02.003

Afsar S.S., Kumar S. and Alam P. (2015) Characterization of leachate at various landfill site of Delhi (India). International Journal In Advanced technology in Engineering and Science 3(1).

APHA, (1998): Standard Methods for Examination of Water and Wastewater. 19th ed., American Public Health Association, Washington, DC.

Aziz H.A., Alias S., Adlan M. N., Asaari F. A. H. and Zahari M. S. M. (2007) Colour removal from landfill leachate by coagulation and flocculation process. Bioresource Technology 98, 218220.https://doi.org/10.1016/j.biortech.2005.11.013

Bahaaeldin E.A.R., Yusoff I., Samsudin A.R., Yaacob W.Z.W. and Rafek A.G.M. (2010) Deterioration of groundwater quality in the vicinity of an active open-tipping site in West Malaysia. Hydrogeology Journal 18, 997-1006. https://doi.org/10.1007/ s10040-009-0567-3

Bhalla B., Saini M.S. and Jha M.K., (2013): Effect of age and seasonal variations on leachate characteristics of municipal solid waste landfill. International Journal of Research in Engineering and Technology 2(6): 732-745.

Chu L.M., Cheung K.C. and Wong M.H. (1994) Variations in the chemical properties of landfill leachate. Journal of Environmental management 18(1): 105-117. https://doi.org/10.1007/ BF02393753

Ehrig H.J. (1983) Quality and quantity of sanitary landfill leachate. Waste Management \& Research 1, 53-68. https://doi. org/10.1177/0734242X8300100105 remained nearly constant afterwards. The LPI is a means to quantify and evaluate in a uniform way the leachates' contamination potential resulting from landfills. Elevated LPIs demonstrate that the leachates produced from landfills have not yet been stabilised resulting in high pollution threat. Thus, from the estimation of LPIs for the leachates studied, it was evident that the pollution threat from the landfill sites of Central Macedonia exists from both fresh waste and aged leachate.

Guerrero-Rodríguez D., Sánchez-Yáñez J.M., Buenrostro-Delgado O. and Márquez-Benavides L., (2014): Phytotoxic effect of landfill leachate with different pollution indexes on common bean. Water, air, and soil pollution 225(6): 2002-2009. https:// doi.org/10.1007/s11270-014-2002-1

Kale S.S., Kadam A.K., Kumar S. and Pawar N.J. (2010) Evaluating pollution potential of leachate from landfill site, from the Pune metropolitan city and its impact on shallow basaltic aquifers. Environmental monitoring and assessment 162(14): 327-346. https://doi.org/10.1007/s10661-009-0799-7

Kumar D. and Alappat B.J. (2004) Selection of the appropriate aggregation function for calculating Leachate Pollution Index. Practice Periodical of Hazardous, Toxic, and Radioactive Waste Management 8(4): 253-264. https://doi.org/10.1061/ (ASCE) 1090-025X(2004)8:4(253)

Kumar D. and Alappat B.J. (2005a) Analysis of leachate pollution index and formulation of sub-leachate pollution indices. Waste Management and Research 23(3): 230-239. https://doi. org/10.1177/0734242X05054875

Kumar D. and Alappat B.J. (2005b) Evaluating leachate contamination potential of landfill sites using leachate pollution index. Clean Technologies and Environmental Policy 7(3): 190197. https://doi.org/10.1007/s10098-004-0269-4

Lema J.M., Mendez R. and Blazquez R. (1988) Characteristics of landfill leachates and alternatives for their treatment: A review. Water, air, and soil pollution 40(3-4): 223-250.

LFTGN02 (2003) Guidance on Monitoring of Landfill Leachate, Groundwater and Surface Water, Environmental Agency, LFTGN02, On line at: www.environment-agency.gov.uk

Manning D.A.C. and Robinson N. (1999) Leachate-mineral reactions: implications for drainage system stability and clog- 
ging. Proceedings of the 7th International WM and Landfill Symposium, October 4-8, Cagliari, Italy, 269-276.

Mor S., Ravindra K., Dahiya R.P. and Chandra A. (2006) Leachate characterization and assessment of groundwater pollution near municipal solid waste landfill site. Environmental monitoring and assessment 118(1-3): 435-456. https://doi. org/10.1007/s10661-006-1505-7

Naveen B.P., Sivapullaiah P.V. and Sitharami T.G. (2015) Effect of aging on the leachate characteristics from municipal solid waste landfill. Proceedings of the 15th Asian Regional Conference on Soil Mechanics and Geotechnical Engineering, ARC 2015: New Innovations and Sustainability, 1940. https://doi. org/10.3208/jgssp.IND-06

Ngilangil L.E., Mendoza M.B. and Vilar D.A. (2015) Groundwater Pollution and Characterization of Leachates from Waste Disposal Facilities in Region 1, Philippines. ARPN Journal of Science and Technology 5(11): 598-608.

Robinson H.D. and Barr M.J., (1999): Aerobic biological treatment of landfill leachates, Waste Management Research 17 , 478-486. https://doi.org/10.1177/0734242X9901700612

Silpa K., Yao L., Bhada-Tata P. and Van Woerden F. (2018) What a Waste 2.0: A Global Snapshot of Solid Waste Management to 2050. Urban Development Series. Washington, DC: World Bank. doi:10.1596/978-1-4648 -1329-0.

Szymański K., Siebielska I., Janowska B. and Sidełko R. (2018)
Variations in physical and chemical parameters of landfill leachates over tim. Desalination and Water Treatment 117 , 149-155.https://doi.org/10.5004/dwt.2018.22201

Tatsi A.A. and Zouboulis A.I. (2002) A field investigation of the quantity and quality of leachate from a municipal solid waste landfill in a Mediterranean climate (Thessaloniki, Greece). Advances in Environmental Research 6(3): 207-219. https://doi. org/10.1016/S1093-0191(01)00052-1

Torretta V., Ferronato N., Katsoyiannis I.A., Tolkou A.K. and Airoldi M. (2017) Novel and conventional technologies for landfill leachates treatment: A review. Sustainability (Switzerland) 9(1): 9-48. https://doi.org/10.3390/su9010009

Umar M., Aziz H.A. and Yusoff M.S. (2010) Trends in the use of Fenton, electro-Fenton and photo-Fenton for the treatment of landfill leachate. Waste Management 30(11): 2113-2121. https://doi.org/10.1016/j.wasman.2010.07.003

Yang H., Yue B., Liu Y., Wu X., Gao H., Zhang Z. and Yan Z. (2019) Rural solid waste-characteristics and leachate pollution assessment for different precipitation levels, China. Environmental Science and Pollution Research (Article in Press) https://doi.org/10.1007/s11356-019-04427-4

Zainol N.A., Aziz H.A. and Yusoff M.S. (2012) Characterization of Leachate from Kuala Sepetang and Kulim Landfills: A Comparative Study. Energy and Environment Research 2(2): 45-52. https://doi.org/10.5539/eer.v2n2p45 